\title{
S. Marciano, P. Pellicanò, "... secondo il mio cuore..." (Ger 3, 15) Sessualità, affettività e vocazione all'amore: un itinerario formativo, un cammino spirituale San Paolo Edizioni 2001, ss. 407
}

Autor książki S. Marciano, obecnie Arcybiskup Metropolita Rossano-Cariati i sekretarz Konferencji Episkopatu Kalabrii, przez wiele lat pełnił funkcję formatora w Arcybiskupim Seminarium Piusa XI w Reggio Calabria. We współpracy z P. Pellicanò, świecką psycholog, włączoną w formację do kapłaństwa we wspomnianym kalabryjskim seminarium, Marciano stworzył swoisty podręcznik wychowania do czystości, wsparty o piękno zamysłu Stwórcy w ludzkiej tożsamości uczuciowo - płciowej i miłości.

Inspiracją do powstania książki były nie tylko lata praktyki formacyjnej, ale także nauczanie Karola Wojtyły jako profesora Katolickiego Uniwersytetu Lubelskiego, biskupa i papieża o ludzkim ciele, płciowości i miłości. Stąd autorzy odwołują się w swoim studium do takich dzieł jak Miłość i odpowiedzialność, Osoba $i$ czyn, czy też wypowiedzi Papieża skierowanych do kapłanów i osób konsekrowanych odnoszących się do celibatu i ewangelicznej rady czystości. $\mathrm{W}$ ten sposób całość pracy jawi się nie jak podręcznik do ascezy, dedykowany studiującym problematykę ludzkiej płciowości w kontekście powołania do bezżennej czystości, ale raczej jak dialog tematycznie usystematyzowany, przydatny dla wszystkich, duchownych i świeckich, którzy chcą poznać i przeżyć miłość w jej różnych formach i powołaniach.

Drogę do wyznaczonego celu pracy autorzy rozpoczynają od wnikliwej analizy płciowości wpisanej w kontekst osoby. W tworzeniu pojęcia „seksualności uduchowionej" pomaga im teologia ciała ludzkiego stworzona przez Karola Wojtyłę w książce Miłość i odpowiedzialność. Człowiek, będąc osobą, odkrywa siebie jako zdolnego do miłości. Uczy się jej poprzez zmierzenie się z dojrzewaniem uczuć, wzrastanie w świadomości bycia osobą i podejmowanie refleksji nad znaczeniem i wartością ludzkiej seksualności, a przez to odkrywanie w niej pełni ludzkiego życia, powołania do świętości poprzez życie w czystości. W tak rozumianym powołaniu osoba duchowna odkrywa swój cel - bycie ewangelizatorem miłości, który staje się imperatywem do poznania prawdy o ludzkiej miłości i seksualności, o powołaniu do małżeństwa i rodziny. Nie chodzi tu bynajmniej o technikę, czy poznanie intelektualne, ale o osobiste doświadczenie zakochania się w miłości i życiu, które oznaczają Boga, a jednocześnie wyrażają ludzką seksualność.

Analizując sferę ludzkich uczuć, autorzy podkreślają ich znaczenie przy dokonywaniu wyborów. Aby były one słuszne, także w kontekście powołania 
chrześcijańskiego, muszą być dokonywane przez osobę zintegrowaną tzn. taką, która podporządkowana jest temu, co racjonalne, duchowe i transcendentne. W tym kontekście odwołują się także do klasycznych ujęć rozwoju psychiczno-uczuciowego, jak choćby tych stworzonych przez amerykańskiego psychoanalityka Erika Eriksona.

Rozwój osobowy chrześcijanina ściśle łączy się z jego pracą wewnętrzną. Autorzy podkreślają konieczność kształtowania w chrześcijaninie cnoty nadziei. Bez względu na doświadczenie przeszłości, w porządku historii zbawienia, niemożliwe jest zakwalifikowanie człowieka do „doskonałych” lub „do niczego”. Świadome poddawanie się procesowi rozwojowemu domaga się w każdym przypadku cierpliwości ze sobą samym, umotywowanej miłością, do której należy dodać pokorę. Rozwój psychiczny wspomagany jest także odniesieniami moralnymi, rozumianymi nie jako hamulec, ale światło, które oświeca drogę, czyniąc ją bardziej bezpieczną.

Kolejnym etapem w odkrywaniu prawdy o płciowości człowieka jest umieszczenie jej w kontekście uczuć. Autorzy podkreślają potrzebę właściwego miejsca uczuciowości w modlitwie, życiu duchowym, relacjach z jednoczesną świadomością, że nie może ona ich zdominować. Żyjąc w konsekrowanej czystości nie można zapomnieć o wychowaniu do właściwie umotywowanych wyborów wartości. W konsekwencji ma to doprowadzić do przejścia od potrzeby do wartości, od działania na wskroś instynktownego do rozumowego. W tym względzie ważne miejsce zajmuje pojęcie relacji międzyosobowych pojmowanych nie jako środek dla zaspokojenia potrzeby, ale jako wartość, dobro nie dla siebie samego, ale dobro w sobie.

W dalszej części rozważań nad ludzką płciowością, autorzy podejmują niezwykle ważny w formacji do kapłaństwa i życia konsekrowanego problem naturalnych uwarunkowań człowieka i łaski. Ta ostatnia zawsze jest odpowiednia naturze człowieka, udoskonala ją, nigdy zaś nie jest jej przeciwstawna.

Człowiek jest bytem cielesno - duchowym. Oznacza to, że każdy wymiar jego istnienia musi zawierać wzajemne przenikanie się tego co duchowe i materialne. Także płciowość, by wyrażała siebie na sposób ludzki musi być uduchowiona. Jako taka ma nosić w sobie znamiona obrazu Boga widoczne najwyraźniej w płodnej komunii kobiety i mężczyzny, w zdolności do miłości i życia rozumianego nie tylko w charakterze daru, ale także zadania wyrażającego się w zdolności rozrodczej.

W powołanie do kapłaństwa i życia konsekrowanego wpisana jest nieodłącznie samotność, która dotyka także ludzkiej płciowości. Zdolność ta jest pozytywnym wyznacznikiem powołania w zachodniej dyscyplinie kościelnej, związanej z bezżenną czystością. Samotność nabiera znaczenia pozytywnego tylko wówczas, kiedy staje się preludium do komunii osób. Kapłan, osoba zakonna godzą się dobrowolnie na samotność, by dzięki niej wchodzić w przenikniętą czystością komunię osób. Ta jedność nie dopuszcza właściwej małżeństwu wyłączności. 
Poprzez jedność z Bogiem prowadzi do jedności z powierzoną wspólnotą. W tym kontekście oblubieńczy charakter ludzkiego ciała służy, by objawić miłość siostrom i braciom w wierze, jak również stać się czytelnym znakiem dla wszystkich poszukujących prawdy.

Teologia ciała wprowadza w pedagogikę ciała, w wychowanie. Jego skuteczność mierzy się przejściem ku autowychowaniu wyrażającym się w umiejętności dokonywania właściwych powołaniu wyborów. Autorzy odwołują się w tym względzie do bł. Jana Pawła II, który mówił o dwóch wymiarach bezżennej czystości: moralnym i charyzmatycznym. Pierwszy rozumiany jest jako cnota - stałe usposobienie człowieka do wykonywania aktów dobrych, odpowiadających naturze i powołaniu. Drugi wymiar wskazuje na czystość jako dar Ducha Świętego. Osoba powołana musi przenikać siebie świadomością bycia uposażoną w dary, dzięki którym to, co wypływa z powołania możliwe jest do wypełnienia.

Proponowane przez S. Marciano i P. Pellicanò studium nad ludzką płciowością w kontekście formacji duchowej i ludzkiej ukazuje czystość jako przyjęcie daru miłości jednoczącej człowieka. Realizacja tego powołania wpisana jest w kontekst trudu i cierpienia nie dla nich samych, ale dla nadprzyrodzonej radości.

Ks. Radosław Kimsza Politechnika Białostocka 